\title{
Comparison of assay systems for detecting antibodies to nuclear ribonucleoproteins
}

\author{
P Merryman, P Louie
}

\begin{abstract}
The specificity and sensitivity of two commercial enzyme linked immunosorbent assays (ELISAs), Diamedix (Miami, Florida) and Lipogen (Noxville, Tennessee), were assessed and compared with haemagglutination and immunodiffusion assays. Sera from 53 patients with various connective tissue disorders were examined for the presence of antibodies to nuclear antigens (ANA), double stranded DNA (dsDNA), Sm, RNP, SSA/Ro, and SSB/La. Of the 53 patients, 42 were ANA positive, 11 were ANA negative, and 22 had antibodies to dsDNA. Seven patients had antibodies to Sm by haemagglutination assay; these were also positive in both ELISA systems (only five of the seven patients were assayed by the Lipogen ELISA system). Two additional Sm positive values were obtained in each of the ELISA systems but only one of these was positive in both. Ten positive RNP results were obtained by haemagglutination and nine of these were also positive by the Diamedix ELISA. Only eight samples were tested by the Lipogen assay and seven of these were positive. Three additional RNP positive values were obtained by the Diamedix and six by the Lipogen ELISA assays. Of these, only two were positive in both. Antibodies to SSA/ Ro were obtained in 11 patients by immunodiffusion and lines of partial identity were observed in nine. SSB/La antibodies were positive in six patients and two had lines of partial identity. All the SSA/Ro and SSB/La positive sera were also positive in both ELISA systems. Moreoever, eight additional SSA/ Ro positive values were obtained in each of the ELISAs, four of which had partial identity lines in the immunodiffusion assay. Furthermore, three additional SSB/La positive values were obtained by the Diamedix and four by the Lipogen assays. Of these, only two were positive in both ELISAs.
\end{abstract}

This study shows that the above ELISAs are comparable in specificity and sensitivity with haemagglutination assay for detection of antibodies to $\mathrm{Sm}$ and RNP antigens and are more sensitive than immunodiffusion for the detection of SSA/Ro and SSB/La antigens.

In autoimmune disease antibodies directed against nuclear ribonucleoproteins, also known as extractable nuclear antigens (ENA), are clinically important. These antibodies, anti-Sm, anti-RNP, anti-SSA/Ro, and anti$\mathrm{SSB} / \mathrm{La}$, serve as markers for certain connective tissue diseases and are, therefore, of diagnostic importance in the clinical management of rheumatic diseases. Antibodies directed against $\mathrm{Sm}$ are associated with systemic lupus erythematosus (SLE), and anti-RNP antibodies, although present in SLE, represent a dominant marker of mixed connective tissue disease (MCTD). Antibodies to both SSA/Ro and SSB/La are characteristic of Sjögren's syndrome and also of SLE.

Antigens recognised by the above antibodies have been identified as subcellular particles composed of nuclear RNAs and protein complexes. ${ }^{1-3}$ These particles also seem to be involved in the splicing of messenger RNAs. ${ }^{4-6}$ Anti-Sm and anti-RNP recognise particles consisting of small nuclear RNA (uRNA) and proteins ranging in molecular mass from 13 to 70 kilodaltons. The antigenic determinants are the proteins and not the RNA components. ${ }^{7-10}$ At least four proteins constitute the antigenic entities of the Sm particles, conventionally known as $B^{\prime}$ (29 kilodaltons), B (28 kilodaltons), D (16 kilodaltons) and $\mathrm{E}$ (13 kilodaltons). The nuclear RNP antigens are proteins of 70, 33 (A) and 22 (C) kilodaltons. ${ }^{1-311}$ SSA/Ro antibodies recognise RNA protein complexes which comprise four to five small RNAs and polypeptides of 52 and 60 kilodaltons. ${ }^{11-13}$ SSB/La antibodies intereact with a particle consisting of a 48 kilodalton polypeptide complexed with nascent RNA polymerase III. ${ }^{14-16}$

In diagnostic immunology the ELISA is the method of choice for detection and quantification of antibodies, but as the commercially available "purified" nuclear ribonucleoprotein antigens or ELISAs for detecting nuclear ribonucleoproteins have not been sufficiently specific, the most commonly used assay systems for determination of antibodies to $\mathrm{Sm}$, $\mathrm{RNP}, \mathrm{SSA} / \mathrm{Ro}$, and SSB/La antigens are haemagglutination and immunodiffusion. Immunodiffusion assay has sufficient specificity, but it is semiquantitative and not highly sensitive. Haemagglutination assay, on the other hand, although specific, sensitive, and quantitative, is a difficult and labour intensive test.

Recently, two different ELISAs for detecting antibodies to Sm, RNP, SSA/Ro, and SSB/La have become available (Diamedix; Miami, Florida, and Lipogen; Noxville, Tennessee). This study set out to compare the specificity and sensitivity of these ELISAs 
with those of haemagglutination and immunodiffusion.

\section{Methods}

Sera from 53 patients with autoimmune disease were analysed for the presence of various autoantibodies and sent to the clinical immunology laboratory for testing.

Antinuclear antibodies were determined by immunofluorescence using mouse liver sections as substrate. Patients' sera (diluted 1 in 20) were incubated with the substrate for 15 minutes at room temperature in a moist chamber. The slides were washed with phosphate buffered saline, (PBS) and goat anti-human globulin conjugated with fluorescein isothiocyanate (FITC) was added and incubated for 15 minutes. The sections were then washed with PBS and read with a fluorescence microscope. The resultant fluorescence was graded on a scale of 0 to 4 . Zero denoted the absence of fluorescence; a grading of 1 was the weakest discernible fluorescence; and a grading of 4 was the strongest.

Antibodies to dsDNA were determined by ELISA. Microwells coated with DNA (calf thymus) and reagents were purchased from Diamedix. Patients' sera were diluted 1 in 40 in PBS and incubated with the coated wells for 30 minutes. After washing the wells goat anti-human globulins, conjugated with the enzyme phosphatase, were added and incubated for 30 minutes. The wells were washed and incubated with the substrate (P-nitrophenyl phosphate) for 30 minutes and read at $405 \mathrm{~nm}$. The results are reported as International Units (IU) per $\mathrm{ml}$.

Human 0 negative cells were washed three times in $0.01 \mathrm{M}$ PBS and incubated at $37^{\circ} \mathrm{C}$ for 30 minutes with $1 \%$ tannic acid. After incubation cells were washed three times in PBS and incubated as above with $15 \mathrm{mg}$ of rabbit thymus extract (Pelfreeze, Brown Deer, Wisconsin). After a second incubation cells were washed three times with PBS containing $2.5 \%$ normal rabbit serum. The cells were then divided into two aliquots. One half was used for the extractable nuclear antigens assay, the other half was digested with $12 \mathrm{mg}$ RNAse at $37^{\circ} \mathrm{C}$ for 30 minutes and used for the $\mathrm{Sm}$ assay. Sera were serially diluted in U-bottom plates starting with a 1 in 4 dilution and $50 \mu \mathrm{l}$ of the coated cells were added to each well. The agglutination titres were read after overnight incubation at room temperature. RNP titres were obtained by subtraction of SM titres from the ENA titres.

Ouchterlony double diffusion plates were purchased from Behring Company (Somerville, New Jersey). Calf thymus extract was used as the antigen (placed in the centre well).

Table 1 Reactivity of ANA positive sera with dsDNA and nuclear ribonuclear antigens

\begin{tabular}{|c|c|c|c|c|c|c|}
\hline $\begin{array}{l}\text { Case } \\
\text { No }\end{array}$ & $\begin{array}{l}\text { ANA } \\
\text { grade }\end{array}$ & $\begin{array}{l}\text { DNA } \\
I U / m l\end{array}$ & $\begin{array}{l}\text { RNP } \\
\text { haemagglutination } \\
\text { titre }\end{array}$ & $\begin{array}{l}\text { SM } \\
\text { haemagglutination } \\
\text { titre }\end{array}$ & $S S A / R o$ & $S S B / L a$ \\
\hline $\begin{array}{l}1 \\
2 \\
3 \\
4 \\
5\end{array}$ & $\begin{array}{l}4 \\
4 \\
4 \\
4 \\
4\end{array}$ & $\begin{array}{r}889 \\
303 \\
458 \\
247 \\
2084\end{array}$ & $\begin{array}{l}0 \\
4 \\
0 \\
8 \\
1\end{array}$ & $\begin{array}{r}13 \\
11 \\
18 \\
2 \\
1\end{array}$ & $\begin{array}{l}\text { PI } \\
\text { PI } \\
\text { PI } \\
\text { Negative } \\
\text { Positive }\end{array}$ & $\begin{array}{l}\text { Negative } \\
\text { Positive } \\
\text { PI } \\
\text { Negative } \\
\text { Negative }\end{array}$ \\
\hline $\begin{array}{r}6 \\
7 \\
8 \\
9 \\
10\end{array}$ & $\begin{array}{l}4 \\
4 \\
4 \\
4 \\
4\end{array}$ & $\begin{array}{l}1275 \\
1536 \\
1254 \\
6208 \\
1200\end{array}$ & $\begin{array}{l}0 \\
0 \\
1 \\
8 \\
1\end{array}$ & $\begin{array}{r}16 \\
7 \\
1 \\
1 \\
1\end{array}$ & $\begin{array}{l}\text { Positive } \\
\text { PI } \\
\text { PI } \\
\text { Negative } \\
\text { PI }\end{array}$ & $\begin{array}{l}\text { Negative } \\
\text { PI } \\
\text { Positive } \\
\text { Negative } \\
\text { Negative }\end{array}$ \\
\hline $\begin{array}{l}11 \\
12 \\
13 \\
14 \\
15\end{array}$ & $\begin{array}{l}4 \\
4 \\
4 \\
4 \\
4\end{array}$ & $\begin{array}{r}830 \\
94 \\
1349 \\
112 \\
407\end{array}$ & $\begin{array}{r}17 \\
1 \\
1 \\
2 \\
3\end{array}$ & $\begin{array}{r}1 \\
1 \\
1 \\
16 \\
22\end{array}$ & $\begin{array}{l}\text { Positive } \\
\text { Negative } \\
\text { Negative } \\
\text { Positive } \\
\text { Negative }\end{array}$ & $\begin{array}{l}\text { Negative } \\
\text { Positive } \\
\text { Negative } \\
\text { Negative } \\
\text { Negative }\end{array}$ \\
\hline $\begin{array}{l}16 \\
17 \\
18 \\
19 \\
20\end{array}$ & $\begin{array}{l}4 \\
3 \\
3 \\
3 \\
3\end{array}$ & $\begin{array}{r}1714 \\
0 \\
216 \\
647 \\
69\end{array}$ & $\begin{array}{l}8 \\
1 \\
1 \\
1 \\
1\end{array}$ & $\begin{array}{l}1 \\
1 \\
1 \\
1 \\
1\end{array}$ & $\begin{array}{l}\text { PI } \\
\text { Negative } \\
\text { Negative } \\
\text { Negative } \\
\text { Negative }\end{array}$ & $\begin{array}{l}\text { Negative } \\
\text { Negative } \\
\text { Negative } \\
\text { Negative } \\
\text { Negative }\end{array}$ \\
\hline $\begin{array}{l}21 \\
22 \\
23 \\
24 \\
25\end{array}$ & $\begin{array}{l}3 \\
3 \\
3 \\
3 \\
3\end{array}$ & $\begin{array}{r}365 \\
463 \\
355 \\
283 \\
1362\end{array}$ & $\begin{array}{r}1 \\
2 \\
1 \\
0 \\
18\end{array}$ & $\begin{array}{l}1 \\
2 \\
1 \\
2 \\
1\end{array}$ & $\begin{array}{l}\text { PI } \\
\text { Negative } \\
\text { Negative } \\
\text { Positive } \\
\text { Positive }\end{array}$ & $\begin{array}{l}\text { Positive } \\
\text { Negative } \\
\text { Negative } \\
\text { Negative } \\
\text { Negative }\end{array}$ \\
\hline $\begin{array}{l}26 \\
27 \\
28 \\
29 \\
30\end{array}$ & $\begin{array}{l}3 \\
3 \\
3 \\
3 \\
2\end{array}$ & $\begin{array}{r}1207 \\
1171 \\
247 \\
809 \\
744\end{array}$ & $\begin{array}{l}8 \\
8 \\
1 \\
1 \\
1\end{array}$ & $\begin{array}{l}2 \\
1 \\
1 \\
1 \\
1\end{array}$ & $\begin{array}{l}\text { Negative } \\
\text { Negative } \\
\text { Negative } \\
\text { Positive } \\
\text { Negative }\end{array}$ & $\begin{array}{l}\text { Negative } \\
\text { Negative } \\
\text { Negative } \\
\text { Negative } \\
\text { Negative }\end{array}$ \\
\hline $\begin{array}{l}31 \\
32 \\
33 \\
34 \\
35\end{array}$ & $\begin{array}{l}2 \\
2 \\
2 \\
2 \\
2\end{array}$ & $\begin{array}{r}524 \\
32 \\
130 \\
32 \\
35\end{array}$ & $\begin{array}{r}13 \\
1 \\
1 \\
1 \\
1\end{array}$ & $\begin{array}{l}1 \\
1 \\
1 \\
1 \\
1\end{array}$ & $\begin{array}{l}\text { Negative } \\
\text { Positive } \\
\text { Negative } \\
\text { PI } \\
\text { Negative }\end{array}$ & $\begin{array}{l}\text { Negative } \\
\text { Positive } \\
\text { Negative } \\
\text { Positive } \\
\text { Negative }\end{array}$ \\
\hline $\begin{array}{l}36 \\
37 \\
38 \\
39 \\
40\end{array}$ & $\begin{array}{l}2 \\
1 \\
1 \\
1 \\
1\end{array}$ & $\begin{array}{r}460 \\
752 \\
77 \\
93 \\
50\end{array}$ & $\begin{array}{l}1 \\
2 \\
2 \\
1 \\
1\end{array}$ & $\begin{array}{l}1 \\
2 \\
1 \\
1 \\
1\end{array}$ & $\begin{array}{l}\text { Negative } \\
\text { Negative } \\
\text { Negative } \\
\text { ND } \\
\text { Positive }\end{array}$ & $\begin{array}{l}\text { Negative } \\
\text { Negative } \\
\text { Negative } \\
\text { Negative } \\
\text { Negative }\end{array}$ \\
\hline $\begin{array}{l}41 \\
42\end{array}$ & $\begin{array}{l}1 \\
1\end{array}$ & $\begin{array}{r}84 \\
101\end{array}$ & $\begin{array}{l}1 \\
1\end{array}$ & $\begin{array}{l}1 \\
1\end{array}$ & $\begin{array}{l}\text { Negative } \\
\text { Positive }\end{array}$ & $\begin{array}{l}\text { Negative } \\
\text { Negative }\end{array}$ \\
\hline
\end{tabular}

Antibodies to nuclear antigens (ANA) were determined by immunofluorescence, dobule stranded DNA (dsDNA) by ELISA, Sm and RNP by haemagolutination, and SSA/Ro and SSB/La by immunodiffusion. Positive test results are for: ANA $>0$, dsDNA $>400 \mathrm{IU} / \mathrm{ml}, \mathrm{Sm}$ and $\mathrm{RNP}>2$ wells and $\mathrm{SSA} / \mathrm{Ro}$ and $\mathrm{SSB} / \mathrm{La}$ are positive. $\mathrm{PI}=$ partial identity. 
Table 2 Haemagglutination and ELISA test results for Sm and RNP antigens

\begin{tabular}{|c|c|c|c|c|c|c|c|}
\hline $\begin{array}{l}\text { Case } \\
\text { No }\end{array}$ & $\begin{array}{l}\text { Haemagglutination } \\
\text { titre }\end{array}$ & $\begin{array}{l}\text { ELISA } \\
\text { (Diamedix) } \\
O D\end{array}$ & $\begin{array}{l}\text { ELISA } \\
\text { (Lipogen) } \\
O D\end{array}$ & $\begin{array}{l}\text { Case } \\
\text { No }\end{array}$ & $\begin{array}{l}\text { Haemagglutination } \\
\text { titre }\end{array}$ & $\begin{array}{l}\text { ELISA } \\
\text { (Diamedix) } \\
O D\end{array}$ & $\begin{array}{l}\text { ELISA } \\
\text { (Lipogen) } \\
O D\end{array}$ \\
\hline $\begin{array}{r}2 \\
15 \\
14 \\
3 \\
6 \\
1 \\
7 \\
16 \\
30 \\
25\end{array}$ & $\begin{array}{l}11 \cdot 0 \\
22 \cdot 0 \\
16 \cdot 0 \\
18 \cdot 0 \\
16 \cdot 0 \\
13 \\
7 \\
\text { Negative } \\
\text { Negative } \\
\text { Negative }\end{array}$ & $\begin{array}{l}1.3 \\
1.03 \\
1.28 \\
1.81 \\
1.95 \\
0.98 \\
1.13 \\
\text { Negative } \\
0.61 \\
0.43\end{array}$ & $\begin{array}{l}\overline{1.6} \\
0 \cdot 75 \\
\overline{2} \cdot 52 \\
2 \cdot 18 \\
2 \cdot 04 \\
0.54 \\
0 \cdot 87 \\
\text { Negative }\end{array}$ & $\begin{array}{r}25 \\
11 \\
31 \\
26 \\
9 \\
4 \\
27 \\
16 \\
2 \\
12 \\
37 \\
22 \\
20 \\
16 \\
13 \\
6 \\
1\end{array}$ & $\begin{array}{c}18 \\
17 \\
13 \\
8 \\
8 \\
8 \\
8 \\
6 \\
4 \\
3 \\
\text { Negative } \\
\text { Negative } \\
\text { Negative } \\
\text { Negative } \\
\text { Negative } \\
\text { Negative } \\
\text { Negative }\end{array}$ & $\begin{array}{l}0.96 \\
1.75 \\
1.27 \\
0.71 \\
1.05 \\
1.31 \\
0.44 \\
\text { Negative } \\
0.54 \\
0.42 \\
0.38 \\
0.49 \\
0.39 \\
\text { Negative } \\
\text { Negative } \\
\text { Negative } \\
\text { Negative }\end{array}$ & $\begin{array}{l}1.35 \\
2 \cdot 18 \\
\text { Negative } \\
1 \cdot 17 \\
\overline{0} \\
0.36 \\
0.63 \\
0.37 \\
-1.38 \\
0.57 \\
1.24 \\
\text { Negative } \\
1.87 \\
0.67 \\
2.21 \\
2.04\end{array}$ \\
\hline
\end{tabular}

Antibodies to $\mathrm{Sm}$ and RNP were determined by haemagglutination and by Diamedix and Lipogen ELISA. Positive test results for haemagglutination is $>2$ wells and for ELISA >0.35 OD.

centre well). Reference antibodies against SSA/Ro or SSB/La were placed in adjacent wells. The resulting precipitin lines were then read in relation to the reference serum.

The ELISA systems for determination of antibodies to Sm, RNP, SSA/Ro and SSB/La antigens were provided by Diamedix and Lipogen. Because sufficient Lipogen ELISA plates were not available, however, only 43 sera were tested in this system. Test procedures were the same as those described for dsDNA, except that the sera were diluted 1 in 100 for Sm, SSA/Ro, and SSB/La and for Lipogen RNP. The dilution for Diamedix RNP was 1 in 400 .

\section{Results and Discussion}

Sera from 53 patients with various connective tissue disorders were first examined for the presence of antibodies to nuclear antigens (ANA). Of the 53 patients, 42 were ANA positive with titres ranging from $1 / 20$ to $1 / 20$, 480 , and 11 were ANA negative (table 1 ). Both the ANA positive and ANA negative sera were then examined for the presence of antibodies to double stranded DNA (dsDNA), Sm, RNP, SSA/Ro and SSB/La antigens. Antibodies to dsDNA, as well as ANA positivity, were used for assessing cross reactivity. Antibody reactivity was determined by different assay systems routinely used in our laboratory. The ELISA was used to determine antibodies to dsDNA, the haemagglutination assay was used for determination of anti-Sm and anti-RNP antibodies and anti-SSA/Ro, and anti-SSB/La antibodies were assayed by immunodiffusion.

Among the 42 ANA positive patients, 22 had antibodies to dsDNA, (table 1) seven had antibodies to $\mathrm{Sm}$, and 10 were positive for RNP. SSA/Ro and SSB/La antibodies were found in 11 and six patients, respectively. Lines of partial identity were also identified in nine patients for SSA/Ro and in two for SSB/La antigens. The ANA negative sera (data not shown) were negative for the above antigens except for one patient who was ANA negative but who showed reactivity against SSA/Ro antigen (data not shown). The ANA negativity in this patient may be due to the extreme solubility of SSA/Ro antigen and its diffusion into the cytoplasmic compartment. In fact, the initial identification of both Ro and La antigens as cytoplasmic seems to have been due to this phenomenon. ${ }^{12}$ Moreover, there is some evidence to suggest that SSA/Ro and SSB/La antigens are present in nuclear or cytoplasmic compartments, depending on the functioning state of the cell ${ }^{12}$ These results show the specificity of the assay systems for detecting antibodies to nuclear ribonucleoproteins. Of the 22 DNA positive patients, only five had antibodies to SSA/Ro antigens and only one was positive for SSB/La antigens; antibodies to $\mathrm{Sm}$ and RNP were detected in five and seven patients, respectively. Sm and RNP antibodies, along with anti-dsDNA antibodies are common in SLE.

We then compared the specificity and sensitivity of the two commercially available ELISA systems with haemagglutination and immunodiffusion assays for the detection of antibodies to Sm, RNP, SSA/Ro and SSB/La antigens. The results show a high degree of concordance among the different test systems, although there were some discrepancies (tables 2 and 3). Sm antibodies were detected in seven patients by haemagglutination assay (table 2 ). These sera were also positive in both ELISAs. Two additional positive results were also obtained by the Diamedix and two by the Lipogen ELISA, but only one of these was positive in both ELISAs (table 2).

The results for RNP antibodies are also shown in table 2. RNP antibodies were positive in 10 patients by the haemagglutination assay, and nine of these were also positive in the Diamedix ELISA. Only eight samples were tested by the Lipogen system, and seven of these were positive. The negative result in each ELISA system, however, did not originate from the same sample. Moreoever, three additional RNP positive results were obtained by Diamedix (all three were of borderline value) and six by Lipogen ELISA assay. Of these, two were positive in both ELISA systems (table 2). The discrepancy in the RNP results, especially those obtained with the Lipogen assay, may have been due to the differences in the experimental systems. In the 
Table 3 Immunodiffusion and ELISA test results for SSA/Ro and SSB/La antigens

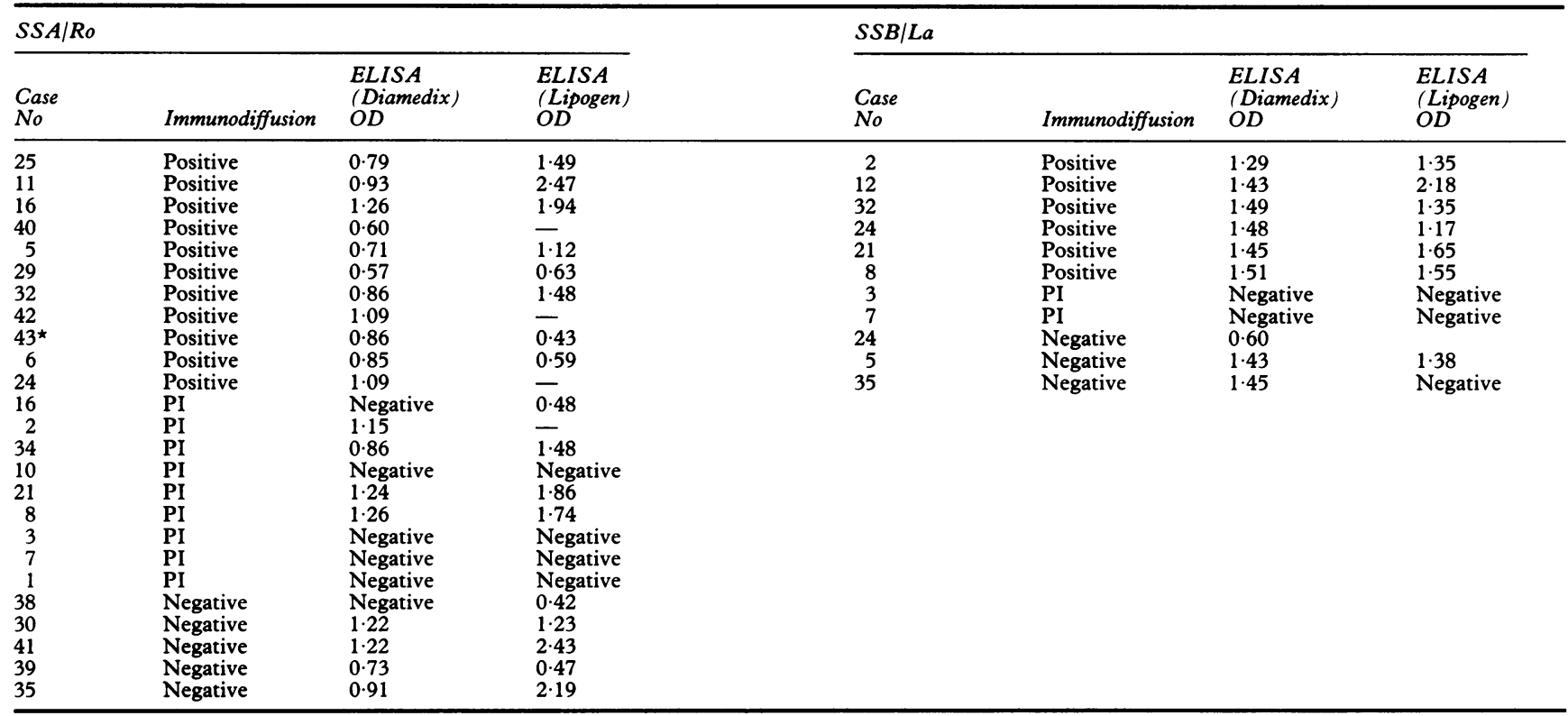

Antibodies to SSA/Ro and SSB/La were determined by immunodiffusion, and by the Diamedix and Lipogen ELISA. Positive tests results for ELISA were $>0 \cdot 35$ $\mathrm{OD}$ and for immunodiffusion were positive. $\mathrm{PI}=$ partial identity.

^ANA negative patient.

haemagglutination and Diamedix ELISAs RNP reactivity is determined by subtracting $S m$ values from the total reactivity to RNP and Sm. In the Lipogen ELISA the 70 and the 33 kilodalton polypeptides (components of the RNP particles) are used as antigen. Thus any cross reactivity in the Sm-RNP system, which is irrelevant in the haemagglutination and Diamedix assays, may remain a factor in the Lipogen system. Conversely, the Lipogen assay may be more sensitive. The question of the possible cross reactivity versus greater sensitivity in Lipogen ELISA was not explored.

Comparison of the SSA/Ro and SSB/La antibodies is shown in table 3. SSA/Ro antibodies were detected in 11 patients by immunodiffusion assay. Lines of partial identity were observed in nine patients. Partial identity lines indicate either cross reactivity of the antibody with a homologous antigen, or masking, or partial distortion of the precipitin line by the immune complexes formed by another antigen antibody reaction. Lines of partial identity are not uncommon when testing for antibodies to nuclear ribonucleoproteins by immunodiffusion, because patients with rheumatic disease often have more than one antibody to these antigens. In fact, this is one of the disadvantages of the above test system, in addition to the lower sensitivity and semiquantitative nature of the test. Antibodies to SSB/La antigens were detected in six patients by the immunodiffusion and two showed lines of partial identity. The SSA/Ro positive sera in the immunodiffusion assay were also positive in both ELISA systems (table 3). Moreover, eight additional positive results were obtained in each of the ELISAs, four of which had lines of partial identity in the immunodiffusion assay. Of the eight additional ELISA values, only six were positive in both ELISA systems (table 3 ).

The sera which were positive for SSB/La antibodies in the immunodiffusion assay were also positive in both ELISA system (table 3). Furthermore, one additional positive result was obtained by Lipogen and three by the Diamedix ELISA. The two sera which had lines of partial identity by the immunodiffusion assays were negative in the Lipogen and Diamedix assays (table 3 ).

These results show that the Lipogen and Diamedix ELISA systems for detection of antibodies to Sm, RNP, SSA/Ro and SSB/La antigens are specific and sensitive. No significant cross reactivity was observed for either system. Although haemagglutination assay is comparable in specificity and sensitivity with the ELISA system, it is a more difficult and labour intensive system. The results also show that ELISA is more sensitive than immunodiffusion, and suggest that the lines of partial identity in the immunodiffusion assay may be the result of either distortion of the precipitin lines, as shown by the reactivity of four sera with partial identity lines in both ELISA systems, or the recognition of homologous antigens, shown by negative ELISA results in five such sera.

1 Northway JD, Tan EM. Differentiation of antinuclear antibodies giving speckled staining patterns in immunofluorescence. Clin Immunol Immunopathol 1972;1:140-52.

2 Mattioli M, Reichlin M. Physical association of two nuclear antigens and mutual occurrence of their antibodies: The relationship of the Sm and RNA protein (Mo) systems in SLE sera. J Immunol 1973;110:1318-24.

3 Lerner MR, Steitz JA. Antibodies to small nuclear RNA complexed with proteins are produced by patients with systemic lupus erythematosus. Proc Natl Acad Sci USA 1979;76:5495-7.

4 Yang VW, Lerner MR, Steitz JA, Flint SJ. A small nuclear ribonucleoprotein is required for splicing of adenoviral early RNA sequences. Proc Natl Acad Sci USA 1981; 78:1371-5.

5 Padgett RA, Mount SM, Steitz JA, Sharp PA. Splicing of messenger RNA precursors is inhibited by antisera to small nuclear ribonucleoprotein. Cell 1983;35:101-7.

6 Bozzoni I, Amaldi F, Anneis F, Beccari E, Fragapare P, Pierandrei-Amaldi $P$. Splicing of Xenopus laevis ribosomal protein RNAs is inhibited in
SnRNP. J Mol Biol 1984;180:1173-8.

7 Habets WJ, Berden JHM, Hoch SO, Van Venrooij WJ Further characterization and subcellular localization of 
Sm and Ul ribonucleoprotein antigens. Eur J Immunol 1985;15:992-7.

8 Weiben ED, Rohleder AM, Nenninger JM, Pederson T. cDNA cloning of a human autoimmune nuclear ribonucleoprotein antigen. Proc Natl Acad Sci USA 1985; 82:7914-18.

9 Mimori T, Hinterberger M, Pettersson I, Steitz JA. Autoantibodies to the U2 small nuclear ribonucleoprotein in a patient with sclerodermapolymyositis overlap syndrome. J Biol Chem 1984;259:560-5.

10 Habets W, Holt M, Bingmann P, Lechrman R, Van Venrooij WJ. Autoantibodies to ribonucleoprotein particles containing U2 small nuclear RNA. EMBO J 1985;4:1545-50.

11 Tan EM. Antinuclear antibodies: diagnostic markers for autoimmune diseases and probes for cell biology. $A d v$ autoimmune diseases and probes for cell biology. Adv

12 Clark G, Reichlin M, Tomasi TB. Characterization of a soluble cytoplasmic antigen reactive with sera from patients with systemic lupus erythematosus. J Immunol

13 Wolin SL, Steitz JA. The Ro small cytoplasmic ribonucleoproteins: identification of the antigenic protein and its binding site of the Ro RNAs. Proc Natl Acad Sci USA 1984;81:1996-2000.

14 Rinke J, Steitz JA. Precursor molecules of both human 5S ribosomal and transfer RNAs are bound by a cellular protein reactive with anti-La antibodies. Cell 1982; 29:149-59.

15 Chan EKL, Francoeur AM, Tan EM. Epitopes, structural domains and asymmetry of amino acid residues in SSB/La nuclear protein. I Immunol 1986;136:3744-49.

16 Chan EKL, Tan EM. The small nuclear ribonucleoprotein SSB/La binds RNA with a conserved protease-resistant domain of $28 \mathrm{KD}$ Mol. Cell Biol 1987;7:2588-91.

\section{Eponyms in pathology ...}

NEISSER, Albert Ludwig Sigmund (1855-1916) was a German dermatologist and microbiologist born in Scheidnitz. He studied in Breslau, qualifying in 1877, and later became Professor of Dermatology there. In 1879 he discovered the bacterial cause of gonorrhoea, later named gonococcus by him in 1882 . He experimented on syphilis in monkeys in Java and was associated with von Wasserman in developing his serological test for syphilis. During research on leprosy in Norway and Spain he identified Mycobacterium leprae which Hansen had seen in 1873 but had not thought to be the cause of leprosy. After his death Saccardo named a genus of the family coccaceae for him (Neisseria) which includes meningococcus. 